\title{
The Future of Two Festivals
}

\author{
By Gerald Pratley \\ Spring 1993 Issue of KINEMA
}

\section{BERLIN 1992}

Flying into Berlin is now so very ordinary. No need to worry about wandering out of the narrow corridor over East Germany leading into the divided city; no fear now of being shot down by a watchful MIG; now the Frankfurt-Berlin train can stop where it likes and motorists can leave the autobahn on the way in. The fear and atmosphere of menace have gone. Checkpoint Charlie has gone; Bernard Samson has come out for the last time. No one will get riddled with bullets trying to cross the Wall because the Wall has disappeared. Was it ever there? Hard to believe as the West Berlin double-deckers pass the Brandenburg Gate and drive straight through to Alexanderplatz. A history of forty years has disappeared, to become a tick in time a hundred years hence.

Surprisingly many former West Berliners are not too happy about this sudden unexpected turn of events. And why? Because before the reunification West Berlin was their very own tight little island, their own "land," independent, generously funded by the West German government a long way away in Bonn and which had no control over it, free to do what it liked under the protection of the three occupying powers, with everyone drawn together by the need to preserve themselves at all cost from an enemy surrounding it on all sides.

But now Berlin is just another big sprawling European city in a big country, now Germany's capital with a government still years away in Bonn, with growing financial and social problems and with two former populations used to different political ways of life finding it extremely difficult to come together under capitalism. The milk of human kindness ran out when the hysteria died down; psychologically the Wall remains even though the guns are gone. It is now a city of no particular distinction with two of everything and twice as much traffic.

This is the background against which the renowned International Film Festival entered its 42nd Year -- the first of the famous three, Berlin, Cannes and Venice; a background that has taken from it, to a certain extent, its noble purpose over the years: the bridging of a bloc of Eastern communist countries by bringing filmmakers and their work into a divided city surrounded by East Germany -- and where friendship and freedom was extended to all who came there under circumstances made dangerous by political conflict.

Now, once again, just as getting here is ordinary, so is the presence of former Eastern European films, their producers, directors, writers, actors, just as ordinary as at the London or Toronto festivals. In fact, the difficulty now is to sort out which countries have become what countries. The former Yugoslavian representative wandered around without a country because six parts of it wanted to be represented and the festival said no. Which makes a new Spanish film, Krapatchouk (directed by Gabriel Lipschutz) seem very timely and appropriate being a comedy about two travellers who set out to visit a country only to find it has disappeared and no one knows where!

So what is the purpose of the Festival now other than to bring together the best (so-called) of the world's filmmaking? Moritz de Hadeln, the Festival Director, speaking to the press on opening night, bravely declared: "Today, when the world is experiencing a resurgence of nationalism and intolerance, we are trying to bring different cultures and people of different backgrounds together. We must consider how the film scene will develop in the former communist countries of Central and Eastern Europe. European co-production is now so extensive that origins are hard to determine. We won't know under what kind of a star this 1992 festival is taking place until it's over."

But for the more than 5000 journalists, delegates, filmmakers, buyers and sellers present and with more than 600 films to choose from, few have time to consider what the stars hold, other than those who appear on screen, and star power in the cinema today is reflected more from the pavement than down from the heavens. The problem for everyone is to decide what films to see, and for journalists the more difficult task of deciding which films to write about for their readers. Even with a daily column no more than 30 to 40 
can be described and commented on in the space allotted to them for the duration of the festival. For a weekly columnist the total is much less.

Berlin has often correctly been described as the natural home of every conceivable form of film making, from radical experimentation, TV documentaries, activist arguments, political revelations explicit sex, all shown in the Forum and Panorama sections along with a cross-section of new films of all kinds on the Market, children's films and marvellous Retrospectives, all topped up so to speak, by the Competition section in which the latest American films -- Cape Fear, Bugsy, Gas Food Lodging, Grand Canyon (winner of the Golden Bear), Paul Schrader's Light Sleeper and Kenneth Branagh's brilliant Dead Again (with Woody Allen's disappointing Shadows and Fog and Nicholas Meyer's Star Trek VI showing out of competition) -all display themselves against the best from the world before taking up their usual dominating position in the European and Far Eastern markets.

What they were up against may well be good, but not unfortunately likely to travel far from their own countries: we saw La Frontera (The Frontier) from Spain/Chile, directed by Riccardo Larrain, a memorable, simple tale of a man banished to a lonely place for political reasons; from Germany, Gudrun, by Hans Geissendorfer, is a 12-year old girl in a small village during the War becoming aware of Nazi activities, and Miraculi by Yorich Weiss, from the former GDR, is a scatterbrained story about a man who has lost his identity, also Der Brocken (The Crumb) by Vadim Glowna, which tells a post-unification tale of a widow whose house suddenly becomes valuable in the property market; Il Capitano (Sweden/France/Denmark) directed by Jan Troell, is yet another account of two teenage delinquents in a life of crime, made different by its Scandinavian settings; from France, Céline, by Jean-Claude Brisseau, is a dream-like portrait of a young woman saved from suicide by a nurse, who then becomes subject to premonitions, and from the splendid Eric Rohmer the second of his "Tales of the Four Seasons" series entitled Conte d'hiver (A Winter's Tale) in which a Parisian hairdresser searches for the father of her child; Rien que des mensonges (Nothing But Lies), is a France/Switzerland co-production from Paule Muret in which Fanny Ardant has an unhappy time at forty contemplating her past life; Edea Emma, Draga Bobe (Sweet Emma, Dear Bobe) concerns itself with the new Hungary seen through the eyes of two school teachers who must change almost overnight from teaching Russian to English, an observant film from István Szabó; Hikarigoke (The Sign of Innocence) is from Japan directed by Kei Kumai and questions the actions of a captain, ship-wrecked 50 years ago, who survived by eating human flesh; El Llarg Hivern (The Long Winter), Spain/France; directed by Jaime Camino, is a very long film about an upper-class family preparing for the arrival of Franco's troops in Barcelona during the long winter of 1939; The Last Days of Chez Nous is Gillian Armstrong's latest film from Australia about a domestic family upheaval in the intense heat of a Sydney summer; Utz (UK/Germany/Italy) directed by George Sluizer, from Holland, and filmed in Prague, is about a Baron with a passion for collecting Meissen porcelain; Ruan Ling Yu was the most popular movie star in the history of Chinese cinema, and this film, a Hong Kong/Taiwan co-production directed by Stanley Kwan retells her life and career, not unlike the melodramatics of most of her films.

Russia was well represented by four films: Andrei Konchalovsky's The Inner Circle (in English and already shown in Canada) is about Stalin's projectionist, and other matters, and to grace the opening the man who was Stalin's projectionist came from Moscow; Infinitas (directed by Marien Chuziev) concerns a man with a double who relives his past in a stream of living memories; Samostojatelnaja Zhizn' (The Independent Life) directed by Vitalij Kanevskij, continues the bleak and haunting story of Valerka in Don't Move, Die and Rise Again (the director's first film) who tries to escape his past in a ship-repair plant in a northern town; and from Georgia, Rchayli (The Beloved) by Michail Kalatosischwili which, set in the time of the Russian revolution, is a family story of the ensuing civil war, its death and destruction, all the more awful for being so quiet and matter-of-fact.

Illustrating more directly perhaps, than any talks and conferences, the dilemma of European production today (The Euro Puddings) with its tangled co-productions and need to find world markets by using English, is the Spanish film, Beltenbros (Prince of Shadows) filmed in English by Pilar Miro, a James Bond-like story, moody and magnificent in place and atmosphere, set during the Franco dictatorship, with Terence Stamp, Patsy Kensit, Geraldine James, John McEnery, all very competent, but is it any wonder that at times we are not quite sure where we are and what we are looking at and which nationality the characters are supposed to represent? Mind you, most Europeans don't really mind because all their films are dubbed into their 
language, so it all seems right enough. But not for us, who would prefer original languages as spoken by their own actors.

Among films by favourite directors, Bertrand Tavernier stepped into Marcel Ophuls' field with a four-hour documentary The Undeclared War, in which young Frenchmen who served in Algeria during the 1954-62 struggle for independence speak out about their time in the army. Aki Kaurismäki presented La vie de Bohème, his interpretation of the story of the opera without the music; and his brother Mika Kaurismäki showed Zombie and the Ghost Train, about a broken- down rock musician's experiences between Helsinki and Istanbul.

Canada was represented through Telefilm, and several independent distributors, with David Cronenberg's Naked Lunch, in competition; Paul Tanna's La Sarrasine, Antonio Tibaldi's On My Own, Roger Cantin's L'Assassin jouait du trombone (Keep an Eye on the Trombone), Norma Bailey's Border Town Café Richard Martin's North of Pittsburgh and the documentaries Deadly Currents by Simcha Jacobovici and Blast 'Em (the work of a New York paparazzi) by Joseph Blasioli. Several other titles already seen in Canada were shown on the market together with short films and children's movies.

Naked Lunch (a Canadian/British co-production with a totally American subject matter) had its admirers and detractors, each on their own side, with a wide range of indifference in between; La Sarrasine is a Quebec film set at the turn of the century in Montreal concerning the hard life of Italian immigrants; On My Own (a Canadian/Australian/Italian co-production filmed in Toronto with Judy Davis) has a fine Ontario presence and tells a sensitive story of a college student with divorced parents; Border Town Café is full of life and energy dealing with characters living in a café on the Manitoba border; North of Pittsburgh (from Vancouver) is set mainly in the US as an Italian widow and her son seek compensation for a dead husband from a mining company; Keep An Eye on the Trombone is a comedy about an out-of-work actor who becomes a security guard for a film studio. It would no doubt be funnier in French than this dubbed-into-English version. As in previous years, Telefilm's reception at the Mohring Café is always among the liveliest of the festival.

Finally, no festival organizes Retrospectives better than Berlin, much to the dismay of those present who only wish they had the time to attend them all rather than chasing the new films. This year there were three: The Babelsberg Studios 1912-1992 with more than fifty classic German films, opening with Das schwarze Los (1913) and including E. A. Dupont's Varieté (1925) and the original Grand Hotel (1927). The second was Patterns of Jewish Life, an extensive program of more than a hundred feature and documentary films, mostly classics of Yiddish cinema of the thirties, together with examples from more recent productions. This Retrospective complemented a major exhibition of the same name in the Martin-Gropius-Bau.

The third was Retrospective: Hal Roach. The producer, who made the Laurel and Hardy comedies, the Topper series, the films of Harry Langdon, Charley Chase, Harold Lloyd, Will Rogers, and the Our Gang series, (among about one thousand others between 1914 and 1955) is now one hundred years old. He attended the opening, careful, cheerful and obliging, with his memory and eyesight unaffected by the passing years. Moviegoers used to talk about "we laughed until we cried." We did just that, a most unusual experience in the cinema of today.

\section{AND A POSTSCRIPT FROM EDINBURGH}

It's been 25 years since I was last here and what was once a purely documentary event has now become a festival of many kinds of films, but still retaining a strong documentary and animated base as befits the country which gave us John Grierson and Norman McLaren. This is a festival which also holds Canada in high regard. Atom Egoyan was here with The Adjuster, received most favourably, next European stop the Valladolid Festival in Spain; the Children's Section included Anne Wheeler's Angel Square, Paul Donovan's George's Island, and Michael Rubbo's Vincent and Me. The Animation Programme was led by Donald McWilliam' s remarkable NFB screen biography Creative Process: Norman McLaren. Good notices were given to Israeli filmmaker Eli Cohen's Montreal-shot The Quarrel with its splendid performances by R. H. Thompson and Saul Rubinek.

Quebec was represented by Marcel Simard's Love-Moi, a sensitive study of teenage delinquency. The irrepressible actress/producer, Daphna Kastner, brought along Bashar Shbib's American film Julia Has Two 
Lovers, a low-low budget effort doing surprisingly well everywhere Daphna has taken it; the equally determined Sugith Varaghese introduced his short film Kumar and Mr. Jones and gave a BBC-2 sponsored Masterclass talk describing the work of the Canadian Centre for Advanced Film Studies in Toronto. Masterclass speakers included Cliff Robertson, Ben Kingsley and novelist-screenwriter William Boyd and Lewis Gilbert whose Stepping Out (filmed in Toronto) was a gala presentation but sadly is not likely to step very far.

Retrospectives were given to John Sayles ending with his latest film, City of Hope, winner of the Critics' Prize, and István Szabó whose latest Meeting Venus, probably the first Eurofilm, was given its world premiere. Szabó's observations during his Masterclass on filmmaking in Hungary today were disturbing. Lindsay Anderson, acerbic as always, gave the BAFTA-Shell/Scotsman Celebrity Lecture on "The Britishness of British Films"; Nagisa Oshima (straight from Toronto where he is preparing his film about Sessue Hayakawa and Valentino) presented his TV documentary Kyoto and held a charming study session.

Other short films included many from Canada in a section of work by international student filmmakers - 76 Trombones (Jesse Hawks, Christopher Cummings), Any Other Day (Mark Gamble), The Big 'F' Word (Cees von Muigwinkel), Know Your Elephant (Alliso Beda), Rites (Daniella Saioni), Renaissance of Life in the Age of Video Reproduction (Andrew Nicholson), Press One to Connect (Lorne Brass) and The Making of Monsters (John Greyson) which was awarded an honourable mention in the Young Filmmaker of the Year category.

Colin Young, Director of the National Film and Television School of Great Britain presented work from the school and spoke admiringly of The Balloon, made by Canadian student Ken Lidster. "We welcome Canadians," he said, "They are always exceptional." An earlier Canadian graduate, David Fine is back in London with his wife Alison Snowden working on their latest piece of animation. (They made the delightful George and Rosemary for the NFB). Richard Condie's (The Big Snit) animation is evident in several commercials on TV.

Most of the off-screen events at Edinburgh are common to other festivals, but is unique with its Music for the Movies competition requiring the participants to write a passage of music for a short excerpt from the silent film Pirates (1920). A new print of Murnau's Tartuffe (1925) was shown with a live musical accompaniment. Even the poster for the festival has a caricature of Charlie Chaplin with a baton in his hand.

Of the five competitive sections, the two main juries were the Charles Chaplin New Directors Award and the Michael Powell Award for the best British feature film of the year. The Chaplin jury (Juan Carlos Frugone - Spain, Jim Hickey - Scotland, Zslot Kezdi Kovács - Hungary, Ellen Waller - Holland and Risa Shuman - Canada) awarded the prize to Belgian Jaco van Dormael for Toto le Héros with Honourable Mention to Waiting, yet another interesting film from an Australian woman director, Janet McKimmie.

The Powell jury members (Lorenzo Cordelli - Italy, Thom Hoffman - Holland, Jurgen Labenski - Germany, Jean Marsh - UK, and myself as chairman) saw twenty new British films, the winning film being The Grass Arena (Gillies MacKinnon), the true story of John Healy, remarkably played by Mark Rylance, who went from being a down-and-out alcoholic to a chess master in a difficult life. The Post Office Norman McLaren Award for best new British animation went to David Anderson's Door. In memory of Scottish filmmaker Bill Douglas, whose Trilogy and Comrades were given special showings, the Channel 4 Young Film Makers Award was named in his honour. This year's recipient was Polish student Janusz Falinski for The Voyage.

This was the 45th Edinburgh Film Festival and its future is uncertain. Lost it seems among the greater Festival events (The Main Festival, The Fringe, The Book Festival, The Jazz Festival) and stuck in its timeplacing among other film festivals, it almost collapsed three years ago when Jim Hickey could no longer cope with the anxieties of running it as well as the Filmhouse, Edinburgh's film theatre. David Robinson, film critic for The Times, came in and has kept it going. His term has now expired and chairman, Murray Grigor, who founded the festival with Forsyth Hardy, has announced the next director, Penny Thomson, formerly of the Scottish Film office, who does not apparently have previous programming ex-perience. What will happen in the coming years is open to speculation and it is hoped that with Sean Connery (who made the Closing presentations) as the Festival's new patron, Edinburgh's happily-disorganized event will continue to play an important part in Scotland' s contribution to world film and its festivals. 


\section{Author Information}

Gerald PRATLEY, OC, LLD, started his career as film critic with the CBC. In 1969, he founded the Ontario Film Institute which he directed until 1990. He has written several books and numerous articles on film, including Torn Sprockets, a history of Canadian cinema. He taught Film History in universities in Toronto and Waterloo, Canada and holds three honorary degrees from Canadian and US universities.

Gerald A. Pratley (1923-2011) was born and educated in London, England, and came to Canada in 1946. He started working in Toronto for the $\mathrm{CBC}$ as a scriptwriter. He was drawn toward working in motion pictures, and became, in 1948, the CBC's first film critic and commentator.

Gerald Pratley broadcast three programmes a week, Pratley at the Movies, The Movie Scene, Music From the Films, and others, until 1975. During this time he also became the first post-war chairman of the Toronto Film Society, chairman of the Toronto and District Film Council and co-founder of the A-G-E Film Society and correspondent for international magazines such as Films and Filming, Film In Review, Variety, Hollywood Quarterly and International Film Guide. During the 1950s he wrote for Canadian Film Weekly and Canadian Film Digest.

He became known as a speaker on all aspects of motion picture art and industry, and was invited to teach film history at the University of Toronto, York University, University of Waterloo, Seneca College and Ryerson Polytechnical University, with individual lectures being given at many other Canadian and US universities and colleges. He has served as a member of various judging panels of competitions and festivals, being one of the members of the first Canadian Film Awards in 1949.

From 1970 to 1975 he was the director of the Stratford (Ontario) International Film Festival, and from 1969 to 1976 he was Chairman of the International Jury of the Canadian Film Awards. He has attended all the world's leading festivals of film, and in particular, for 30 years, the Cannes Festival as CBC correspondent. He has written six books, The Films of Frankenheimer: Forty Years in Film; The Cinema of John Frankenheimer; The Cinema of Otto Preminger; The Cinema of David Lean; The Cinema of John Huston, and Torn Sprockets, a history of the Canadian cinema.

Gerald Pratley has served on the Advisory Boards of the film departments of Ryerson Polytechnical University and Humber College, and as a member of the programme committee of TV Ontario. In 1968 he became the founder-director of the Ontario Film Institute of the Province of Ontario, an organization which has

distinguished itself in archival holdings and public service and is known since 1990 as the Cinematheque of Ontario. He taught Film History courses at the Department of Film and Photography, Ryerson Polytechnic University, Toronto and the University of Waterloo.

In 1984, Gerald Pratley was made a Member of the Order of Canada and in 2003 Officer of the Order of Canada for his service to Canada through film appreciation. He holds Honorary Degrees in Letters and Fine Arts from York and Waterloo Universities (Ont., Canada) and Bowling Green State University (Ohio, USA).

In 2002, Gerald Pratley received a Special Genie Award from the Academy of Canadian Cinema \& Television in recognition of his lifelong dedication to the promotion and his exceptional support of Canadian cinema.

He died on 14 March 2011 in Ontario, Canada. 